\title{
Risk Factors for Abdominal Aortic Aneurysm in Population-Based Studies: A Systematic Review and Meta-Analysis
}

\author{
Emma Altobelli ${ }^{1,2, *}$, Leonardo Rapacchietta ${ }^{2}$, Valerio F. Profeta ${ }^{3}$ and Roberto Fagnano ${ }^{4}$ \\ 1 Department of Life, Health and Environmental Sciences, University of L'Aquila, 67100 L'Aquila, Italy \\ 2 Epidemiology and Biostatistics Unit, Local Health Unit, 64100 Teramo, Italy; \\ leonardo.rapacchietta@gmail.com \\ 3 Department of community Health, Local Health Unit, 64100 Teramo, Italy; valerio.profeta@aslteramo.it \\ 4 Manager of Local Health Unit 4, 64100 Teramo, Italy; roberto.fagnano@aslteramo.it \\ * Correspondence: emma.altobelli@cc.univaq.it; Tel.: +39-0862-434666; Fax: +39-0862-433425
}

Received: 26 October 2018; Accepted: 5 December 2018; Published: 10 December 2018

\begin{abstract}
Abdominal aortic aneurysm (AAA) represents an important public health problem with a prevalence between $1.3 \%$ and $12.5 \%$. Several population-based randomized trials have evaluated ultrasound screening for AAA providing evidence of a reduction in aneurysm-related mortality in the screened population. The aim of our study was to perform a systematic review and meta-analysis of the risk factors for AAA. We conducted a systematic review of observational studies and we performed a meta-analysis that evaluated the following risk factors: gender, smoking habits, hypertension, coronary artery disease and family history of AAA. Respect to a previous a meta-analysis we added the funnel plot to examine the effect sizes estimated from individual studies as measure of their precision; sensitivity analysis to check the stability of study findings and estimate how the overall effect size would be modified by removal of one study; cumulative analysis to evaluate the trend between studies in relation to publication year. Abdominal aortic aneurysm prevalence is higher in smokers and in males. On the other hand, while diabetes is a risk factor for many cardiovascular diseases, it is not a risk factor for AAA. In addition, it is important to underline that all countries, where AAA screening was set up, had high income level and the majority belong to Western Europe (United Kingdom, Sweden, Italy, Poland, Spain and Belgium). Abdominal aortic aneurysm screening is fundamental for public health. It could avoid deaths, ruptures, and emergency surgical interventions if abdominal aortic aneurysm was diagnosed early in the population target for screening.
\end{abstract}

Keywords: abdominal aortic aneurysm; risk factors; observational studies; meta-analysis

\section{Introduction}

Abdominal aortic aneurysm (AAA) is defined as a permanent dilation of the abdominal aorta, with a diameter of $3 \mathrm{~cm}$ or more [1], that generally remains asymptomatic until its rupture. It is the result of a loss of elastic lamina and smooth muscle cells, which could be due to inflammatory agents and matrix metalloproteases [2].

Abdominal aortic aneurysm represents an important public health problem with a prevalence between $1.3 \%$ and $12.5 \%$ in males, and between $0.0 \%$ and $5.2 \%$ in females [3]. In women, it generally appears 10 years later than in males [4]. Abdominal aortic aneurysm represents about $1 \%$ of deaths in males over the age of 65 , causing more than 175,000 deaths worldwide [5]. The mortality rate associated with rupture is very high and varies between $60 \%$ and $80 \%$, early diagnosis and treatment therefore is very important before its rupture [6]. Rupture rates increase markedly with aneurysm diameter; for 
each $0.5 \mathrm{~cm}$ increase in AAA diameter, rates increase by $0.5 \mathrm{~mm} /$ year and rupture rates double [7]. Other more frequent risk factors associated with AAA are: age, gender, hypertension, family history and coronary artery disease [8]. Although the role of hypertension is still controversial [9-12], it is considered a risk factor in some studies [13-15].

Diabetes is a risk factor for many cardiovascular diseases, it is not a risk factor for AAA. On the contrary, it is negatively associated with AAA. This evidence could be associated to therapy with metformin [16-19]. Moreover, it is important to underline that the presence of AAA in a part of the population remains unexplained and other risk factors may be involved as well as an interaction between genetic and epigenetic background [20,21]. Abdominal aorta aneurysm can be easily diagnosed using ultrasound, a simple highly reliable non-invasive reproductive method. Intervention at this stage could reduce the frequency of rupture, reduce mortality and the requirement for emergency hospital treatment.

Several population-based randomized trials have evaluated ultrasound screening for AAA providing evidence of a reduction in aneurysm-related mortality in the screened population [22-25]. Thompson et al. showed the mortality benefit of screening men aged 65-74 for abdominal aortic aneurysm is maintained up to 10 years and cost effectiveness becomes more favorable over time [26].

Furthermore, it has been recently shown that the implementation of a screening system reduces not only costs, but has many benefits in terms of life expectancy [27]. Based on this evidence, the World Health Organization has included AAA screening among the interventions that proved to be cost effective. Despite this, only a few developed countries in the world have set up screening programmes for AAA [28]. At present, US Preventive Service Task Force (USPSTF) guidelines [29], have strongly recommended a one-time AAA screening for men aged $65-75$ who have smoked. The aim of our study was to perform a systematic review and meta-analysis of the literature of the observational studies that evaluated the presence of the following determinants: gender, smoking habits, hypertension, diabetes mellitus, coronary artery disease (CAD) and family history of AAA.

\section{Material and Methods}

\subsection{Search Method for Identification of Studies}

The papers to be included in this systematic review and meta-analysis were sought in the MEDLINE, EMBASE, Scopus, Clinicaltrials.gov, Web of Science, and Cochrane Library databases up to 30 June 2018. The search strategy was conducted using the following terms: Abdominal Aortic Aneurysms OR Aneurysms, Abdominal Aortic OR Aortic Aneurysms, Abdominal OR Abdominal Aortic Aneurysm OR Aneurysm, Abdominal Aortic AND Screening OR Mass Screenings OR Screening, Mass OR Screenings, Mass OR Screenings AND Factor, Risk OR Factors, Risk OR Risk Factor OR Population at Risk OR Risk, Population at OR Populations at Risk OR Risk, Populations at NOT surgical repair. The period considered was 30 June 1990-1 June 2018. Only papers written in English language were considered.

The methodology used is described in Preferred Reporting Items for Systematic reviews and Meta-Analyses (PRISMA) Flow-Chart (Figure 1) [30]. 


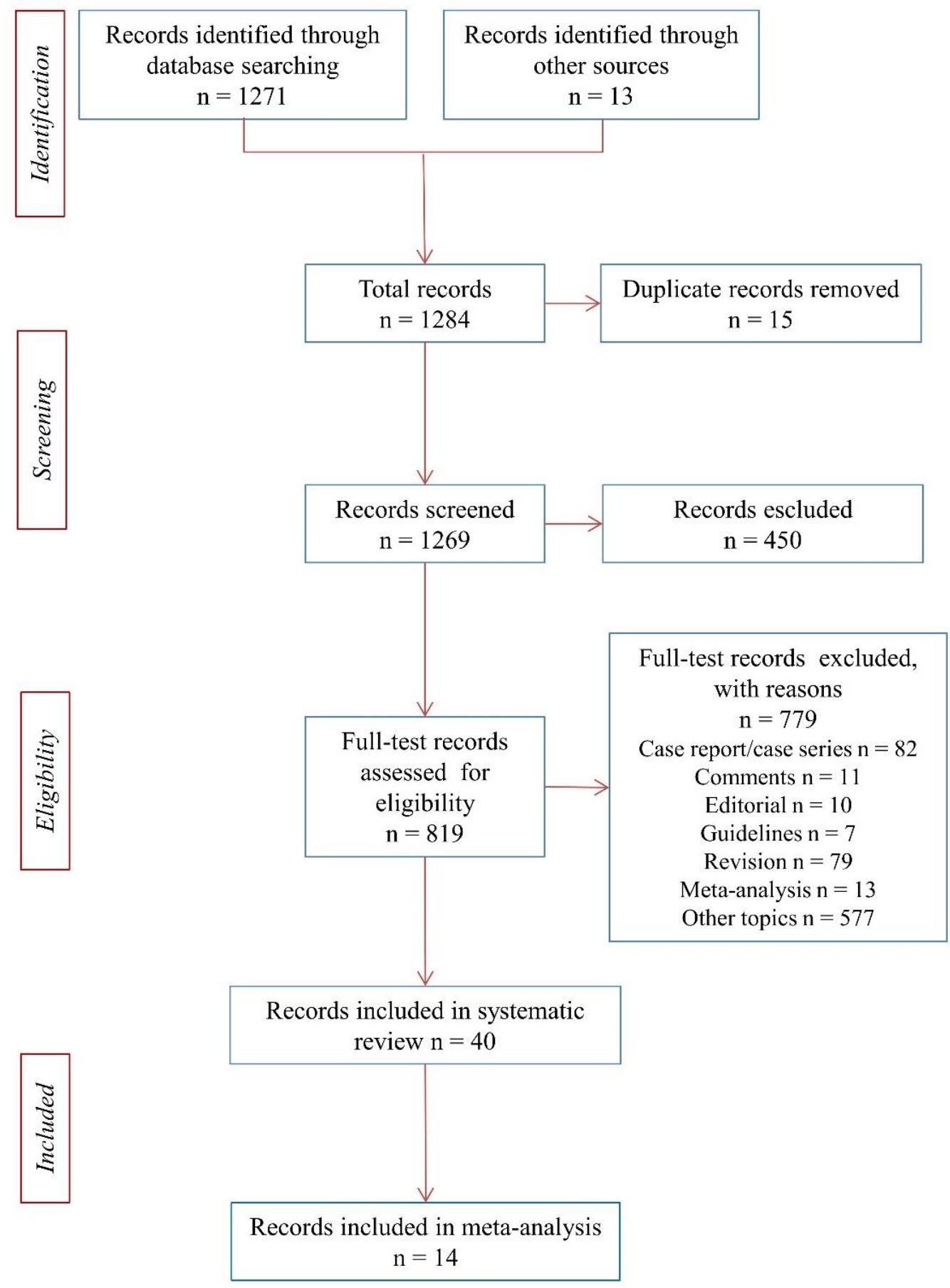

Figure 1. Flow chart of search strategy.

\subsection{Criteria for Selecting Studies}

Determinants as gender, smoking habits, hypertension, diabetes mellitus, family history of AAA and CAD were considered in our Meta-Analysis. All publication years and only English language papers are included in a specific table (Table 1). Observational studies were included in the meta-analysis.

\subsubsection{Participants}

Males and females were considered together. The age of the population target included in our Meta-Analysis varies according to each study. Therefore, a unique range cannot be defined. 


\subsubsection{Outcome}

Abdominal Aortic Aneurysm is a pathology diagnosed when abdominal aorta has a diameter of $3 \mathrm{~cm}$ or more. We included studies that evaluated the potential risk factors associated to AAA and described it above in the eligibility criteria and study design section.

\subsubsection{Quality Assessment}

The papers were selected by two independent reviewers (V.F.P and L.R.); a methodologist (E.A.) resolved any disagreements.

\subsection{Statistical Analysis}

Meta-Analyses were performed when there were at least four studies. Odds ratios (ORs) with $95 \% \mathrm{CI}$ and $p$-value was used as a measure of effect size. A random effect model was applied as a conservative approach to account for different sources of variation among studies. Heterogeneity was assessed using $Q$ statistics and $I^{2}$. Publication bias analysis was estimated using Egger's linear regression test [31], Begg's test [31] and Mazumdar's rank correlation test [32]. The trim and fill procedure was used to check the publication. Finally, meta-regression analyses were performed using publication year as a moderator variable (random effect model) where appropriate.

Prometa 3 (Internovi, Cesena, Italy) was used for all statistical analysis.

\section{Results}

\subsection{Systematic Review of the Literature and Meta-Analysis}

The total number of records identified through database searching was 1271, in addition, records identified through other sources was 13, total records 1284. A total of 15 duplicate records were removed, 1269 total records were screened, and 450 records were excluded. A total of 819 full-test records assessed for eligibility were analyzed. We excluded 779 for following reasons: 82 records because they were case reports/case series, 11 were comments, 10 were editorials, 7 clinical guidelines, 79 were systematic reviews, 13 were meta-analyses that did not include cross-sectional studies on risk factors, 577 were about other topics. A total of 40 papers were considered for systematic review (Figure 1) [4,9-13,15-18,33-62].

The diagnostic test used for screening was ultrasound, except for Denmark where TC scan was used [33].

The selected studies for systematic review and in meta-analysis are summarized in Table 1. Author, year of publication, city or region, age-group, level of participation (\%) or screened people $(n)$ and AAA detection rate (\%) and screening program start were reported. A total of 14 papers were considered in Meta-Analysis, 13 prevalence studies and 1 case-control hospital-based study. 
Table 1. Characteristics of the studies included in the Systematic Review.

\begin{tabular}{|c|c|c|c|c|c|c|}
\hline $\begin{array}{l}\text { Country }^{a} \\
\text { Reference, Year }\end{array}$ & Region & Age-Group & $\begin{array}{l}\text { Level of } \\
\text { Participation (\%) or } \\
\text { Screened People }\end{array}$ & $\begin{array}{l}\text { AAA Detection } \\
\text { Rate (\%) }\end{array}$ & Program Start & $\begin{array}{l}\text { Included in } \\
\text { Meta-Analysis }\end{array}$ \\
\hline \multicolumn{7}{|l|}{ Population-Based } \\
\hline \multicolumn{7}{|l|}{ Italy } \\
\hline Gianfagna, 2018 [13] & Varese, Lombardia & $\begin{array}{l}\text { M 50-75 } \\
\text { F 60-75 }\end{array}$ & $\begin{array}{l}\text { M } 65.3 \\
\text { F } 61.3 \\
\text { T } 63.8\end{array}$ & $\begin{array}{l}\text { M } 1.3 \\
\text { F } 0.3 \\
\text { T } 0.9\end{array}$ & 2013 & Yes \\
\hline Palombo, 2010 [35] & Genoa, Liguria & M, F 65-92 & $\begin{array}{c}\text { M } 61.6 \\
\text { F } 48.8 \\
\text { T } 54.3 \\
\end{array}$ & $\begin{array}{c}\text { M } 10.8 \\
\text { F } 1.1 \\
\text { T } 6.2 \\
\end{array}$ & 2007-2009 & Yes \\
\hline Simoni, 1995 [36] & Genoa, Liguria & M, F 65-75 & M 58.5 & $\begin{array}{l}\text { M } 8.8 \\
\text { F } 0.6 \\
\text { T } 4.4\end{array}$ & 1991-1994 & Yes \\
\hline \multicolumn{7}{|l|}{ Belgium } \\
\hline Makrygiannis, 2016 [4] & $\begin{array}{l}\text { Chaudfontaine, } \\
\text { Liege, Wallonia }\end{array}$ & $\begin{array}{l}\text { M 65-85 } \\
\text { F 74-85 }\end{array}$ & $\begin{array}{l}\text { M } 39.5 \\
\text { F } 31.7 \\
\text { T } 36.0 \\
\end{array}$ & $\begin{array}{l}\text { M } 4.8 \\
\text { F } 1.3 \\
\text { T } 3.6 \\
\end{array}$ & 2014 & \\
\hline Vazquez, 1998 [33] & Liege, Wallonia & M 75-65 & $\mathrm{T} 41.0$ & T 4.5 & 1995 & \\
\hline \multicolumn{7}{|l|}{ China } \\
\hline Kun Li, 2018 [15] & $\begin{array}{l}\text { Zhengzhou City, Middle } \\
\text { China }\end{array}$ & $\begin{array}{l}\text { M, F }<55 \\
\text { M, F 55-75 } \\
\text { M, F }>75\end{array}$ & $\begin{array}{l}\text { M } 2555 \\
\text { F } 2847 \\
\text { T } 5402\end{array}$ & $\begin{array}{l}\text { M } 0.55 \\
\text { F } 0.14 \\
\text { T } 0.33\end{array}$ & 2014-2015 & Yes \\
\hline \multicolumn{7}{|l|}{ Denmark } \\
\hline Dahl, 2018 [61] & Viborg, Central Denmark & $\begin{array}{c}\text { F (Born 1936, 1941, } \\
\text { 1946, 1951) }\end{array}$ & F 107,491 & NR & 2011-2013 & \\
\hline Kvist, 2016 [34] & $\begin{array}{l}\text { Northen part of Funen and } \\
\text { City of Odense }\end{array}$ & T $65-74$ & $\begin{array}{l}\text { M } 64.9 \\
\text { F } 63.0\end{array}$ & $\begin{array}{l}\text { M } 12.4 \\
\text { F } 1.1\end{array}$ & 2014-2015 & \\
\hline \multicolumn{7}{|l|}{ Poland } \\
\hline Dereńzíski, 2017 [11] & $\begin{array}{c}\text { Gniewkowo, Central } \\
\text { Poland }\end{array}$ & $\begin{array}{l}M>60 \\
\mathrm{~F}>65\end{array}$ & M 61.0 & $\begin{array}{l}\text { M } 6.3 \\
\text { F } 0.82 \\
\text { T } 4.12\end{array}$ & 2009-2012 & yes \\
\hline Janwien, 2014 [37] & Kuyavia-Pomeranian & $M>60$ & M 1556 & M 6.0 & 2009-2011 & \\
\hline
\end{tabular}


Table 1. Cont

\begin{tabular}{|c|c|c|c|c|c|c|}
\hline $\begin{array}{l}\text { Country }^{a} \\
\text { Reference, Year }\end{array}$ & Region & Age-Group & $\begin{array}{l}\text { Level of } \\
\text { Participation (\%) or } \\
\text { Screened People }\end{array}$ & $\begin{array}{l}\text { AAA Detection } \\
\text { Rate (\%) }\end{array}$ & Program Start & $\begin{array}{l}\text { Included in } \\
\text { Meta-Analysis }\end{array}$ \\
\hline \multicolumn{7}{|l|}{ Population-Based } \\
\hline \multicolumn{7}{|l|}{ Spain } \\
\hline Sisó-Almirall, 2017 [38] & $\begin{array}{l}\text { Barcelona, } \\
\text { Catalonia }\end{array}$ & M 60-65 & M 74.9 & M 1.5 & 2013 & \\
\hline Salcedo Jódar, 2014 [9] & $\begin{array}{c}\text { Ciudad Real, Castilla La } \\
\text { Mancia }\end{array}$ & M 65-80 & M 93.5 & M 3.3 & 2012 & \\
\hline Salvador-González, 2016 [10] & $\begin{array}{l}\text { Barcelona, } \\
\text { Catalonia }\end{array}$ & M 65-74 & M 66.9 & M 2.3 & 2007 & \\
\hline Barba, 2013 [59] & Asturias & M (born in 1943) & M 70.8 & M 4.7 & 2013 & \\
\hline \multicolumn{7}{|l|}{ Sweden } \\
\hline Johansson, 2018 [63] & $\begin{array}{c}\text { Uppsala, Dalarna, } \\
\text { Södermanland, Västra } \\
\text { Götaland }\end{array}$ & $M>65$ & M 25,265 & NR & 2006-2009 & \\
\hline Stackelberg, 2017 [40] & Vastmanland, Orebro & M 65-75 & M 49.0 & M 1.2 & 2007-2009 & \\
\hline Wanhainen, 2016 [41] & $\begin{array}{l}\text { All Nation except Halland } \\
\text { Country }\end{array}$ & M 65-75 & M 84.0 & M 1.5 & 2006-2014 & \\
\hline Hager, 2013 [42] & Őstergötland & $\mathrm{M}>70$ & M 84.0 & M 3.0 & $2008-2010$ & \\
\hline Svensjö, 2013 [43] & Uppsala and Darlana & $\mathrm{F}>70$ & M 74.2 & F 0.4 & $2007-2009$ & \\
\hline Svensjö, 2011 [44] & $\begin{array}{c}\text { Uppsala, Darlana, } \\
\text { Sörmland, Gävleborg }\end{array}$ & $M>65$ & M 85.0 & M 1.7 & 2006-2010 & \\
\hline \multicolumn{7}{|l|}{ United Kingdom } \\
\hline Oliver-Williams, 2018 [58] & Gloucestershire, England & M 65 & M 80.7 & M 1.9 & 1990-2015 & \\
\hline Kanagasabay, 1996 [45] & London, England & M, F 65-80 & NR & $\begin{array}{c}\text { M } 7.6 \\
\text { F } 1.3 \\
\end{array}$ & 1995 & Yes \\
\hline Smith, 1993 [46] & Birmingham, England & M 65-75 & M 76.3 & T 8.4 & 1981-1999 & \\
\hline Grismhaw, 1994 [47] & Birmingham, England & M, F 60-75 & M 76.1 & M 7.2 & 1989-1991 & \\
\hline
\end{tabular}


Table 1. Cont

\begin{tabular}{|c|c|c|c|c|c|c|}
\hline $\begin{array}{l}\text { Country }^{a} \\
\text { Reference, Year }\end{array}$ & Region & Age-Group & $\begin{array}{l}\text { Level of } \\
\text { Participation (\%) or } \\
\text { Screened People }\end{array}$ & $\begin{array}{l}\text { AAA Detection } \\
\text { Rate (\%) }\end{array}$ & Program Start & $\begin{array}{l}\text { Included in } \\
\text { Meta-Analysis }\end{array}$ \\
\hline \multicolumn{7}{|l|}{ Population-Based } \\
\hline \multicolumn{7}{|l|}{ Norway } \\
\hline Singh, 2001 [48] & Tromsø & M, F 25-84 & $\begin{array}{l}25-4462.0 \\
45-5481.0 \\
55-6483.0 \\
65-7479.0 \\
75-8458.0\end{array}$ & $\begin{array}{l}\text { M } 9.7 \\
\text { F } 2.2 \\
\text { T } 4.7\end{array}$ & 1994-1995 & Yes \\
\hline \multicolumn{7}{|l|}{ Japan } \\
\hline Takei, $1995 *$ [52] & Ueno, Central Japan & M, F 60-79 & M 69.0 & $\begin{array}{l}\text { M } 3.9 \\
\text { F } 5.0 \\
\text { T } 4.6\end{array}$ & 1992 & \\
\hline \multicolumn{7}{|l|}{ United States } \\
\hline Alcorn, 1996 [57] & Pittsburgh cohort & M, F >65 & T 656 & Т 2.9 & 1990-1992 & Yes \\
\hline \multicolumn{7}{|l|}{ Not Population-Based } \\
\hline \multicolumn{7}{|l|}{ Australia } \\
\hline Nicholls, 1992 [51] & Perth & M, F 60-80 & Т 1225 & $\begin{array}{l}\text { M } 4.7 \\
\text { F } 0.35 \\
\text { T } 2.64\end{array}$ & 1991 & Yes \\
\hline \multicolumn{7}{|l|}{ Italy } \\
\hline Corrado, 2016 [19] & Como, Lombardia & M, F 60-85 & Т 1555 & $\begin{array}{l}\text { M } 2.5 \\
\text { F } 0.4 \\
\text { T } 1.4 \\
\end{array}$ & 2010-2013 & Yes \\
\hline \multicolumn{7}{|l|}{ France } \\
\hline Laroche, 2015 [18] & $\begin{array}{l}\text { All Nation (metropolitan and } \\
\text { overseas departement } \\
\text { "Operation Vésale") }\end{array}$ & M 50-75 F 60-75 & Т 6691 & $\begin{array}{l}\text { M } 3.1 \\
\text { F } 0.3 \\
\text { T } 1.7\end{array}$ & 2013 & \\
\hline \multicolumn{7}{|l|}{ Greece } \\
\hline Makrygiannis, 2018 [60] & Larissa, Central Greece & NR & NR & NR & $2010-2013$ & Yes \\
\hline
\end{tabular}


Table 1. Cont.

\begin{tabular}{|c|c|c|c|c|c|c|}
\hline $\begin{array}{l}\text { Country }{ }^{a} \\
\text { Reference, Year }^{-}\end{array}$ & Region & Age-Group & $\begin{array}{l}\text { Level of } \\
\text { Participation }(\%) \text { or } \\
\text { Screened People }\end{array}$ & $\begin{array}{l}\text { AAA Detection } \\
\text { Rate (\%) }\end{array}$ & Program Start & $\begin{array}{l}\text { Included in } \\
\text { Meta-Analysis }\end{array}$ \\
\hline \multicolumn{7}{|l|}{ Not Population-Based } \\
\hline \multicolumn{7}{|l|}{ Spain } \\
\hline Belloch García, 2018 [16] & La Ribera, Spain & $\mathrm{T}>50$ & Т 241 & Т 2.9 & 2016-2017 & \\
\hline Ortega-Martín, 2007 [39] & León & M 65-75 & M 66.0 & M 4.2 & 2000-2001 & \\
\hline \multicolumn{7}{|l|}{ Norway } \\
\hline Krohn, $1992 *$ [49] & Oslo & M, F 60-89 & T 500 ** & NR & 1991 & \\
\hline Krohn, $1992 *$ [49] & Oslo & M, F 60-89 & T $500 * *$ & NR & 1991 & \\
\hline \multicolumn{7}{|l|}{ Switzerland } \\
\hline Engelberger, 2017 [50] & Lugano, Ticino & M 65-80 & M 68.2 & M 4.1 & 2013 & \\
\hline \multicolumn{7}{|l|}{ Saudi Arabia } \\
\hline Al-Zahrani, 1996 [53] & $\begin{array}{c}\text { Jeddah, Western Saudi } \\
\text { Arabia }\end{array}$ & M, F 60-80 & NR & Т 2.0 & 1991-1992 & Yes \\
\hline \multicolumn{7}{|l|}{ Turkey } \\
\hline Kilic, 2018 [12] & Turkey & $\mathrm{T} \geq 65$ & T 1948 & Т 3.7 & 2016-2017 & Yes \\
\hline \multicolumn{7}{|l|}{ United States } \\
\hline Chun, 2016 [54] & $\begin{array}{l}\text { North Carolina (Veterans } \\
\text { Affair Health care system) }\end{array}$ & M 65-75 & Т 9571 & Т 7.1 & 2007-2011 & \\
\hline Kent, 2010 [55] & All Nation & $\mathrm{M}, \mathrm{F}<85$ & T 3,056,455 & $\begin{array}{l}\text { M } 1.7 \\
\text { F } 0.2 \\
\text { T } 0.7 \\
\end{array}$ & 2003-2008 & Yes \\
\hline Lederle, 2000 [56] & $\begin{array}{c}15 \text { Department of veterans } \\
\text { affair }\end{array}$ & M, F 50-79 & NR & Т 1.4 & 1994-1997 & \\
\hline
\end{tabular}

Legend; NR: Not Reported; E: Echography; M: Male; F: Female; T: Total Sample Size; ${ }^{a}$ All countries have high income level; ${ }^{*}$ Aorta diameter $>2.5 \mathrm{~cm} ;{ }^{* *}$ The study report only the results of first 500 patients. 


\subsubsection{Gender}

Thirteen studies, among those selected, reported information on males versus females. The overall effect size was $\mathrm{OR}=5.93(4.26-8.25), p<0.0001$, with $\mathrm{Q}=132.89, \mathrm{I}^{2}=90.97, p<0.0001$ (Figure 2A and Table 2). Sensitivity analysis shows an equal trend among studies (Figure 2B). Cumulative analysis indicated that all the studies agreed except for Nicholl's [51] and Simoni's [36] (Figure 2C). Although publication bias analysis, by the trim and fill method filled two studies (Figure 2D), the results of Egger's linear regression test and Begg's and Mazumdar's rank correlation tests were not statistically significant ( $p=0.339$ and $p=0.542$, respectively) (Table 2). Meta-regression analysis was not statistically significant $p=0.058$.

A
Alcorn et al. 1996
Corrado ct al. 2016
Derenziski ct al. 2017
Gianfagna et al. 2018
Kanagasabay et al. 1996
Kent et al. 2010
Kilic et al. 2018
l.i ct al. 21118
Makrygiannis et al. 2016
Nicholls et al. 1992
Palombo et al. 2010
Simoni et al. 1995
Sing et al . 2001
Overall (random-effects model)
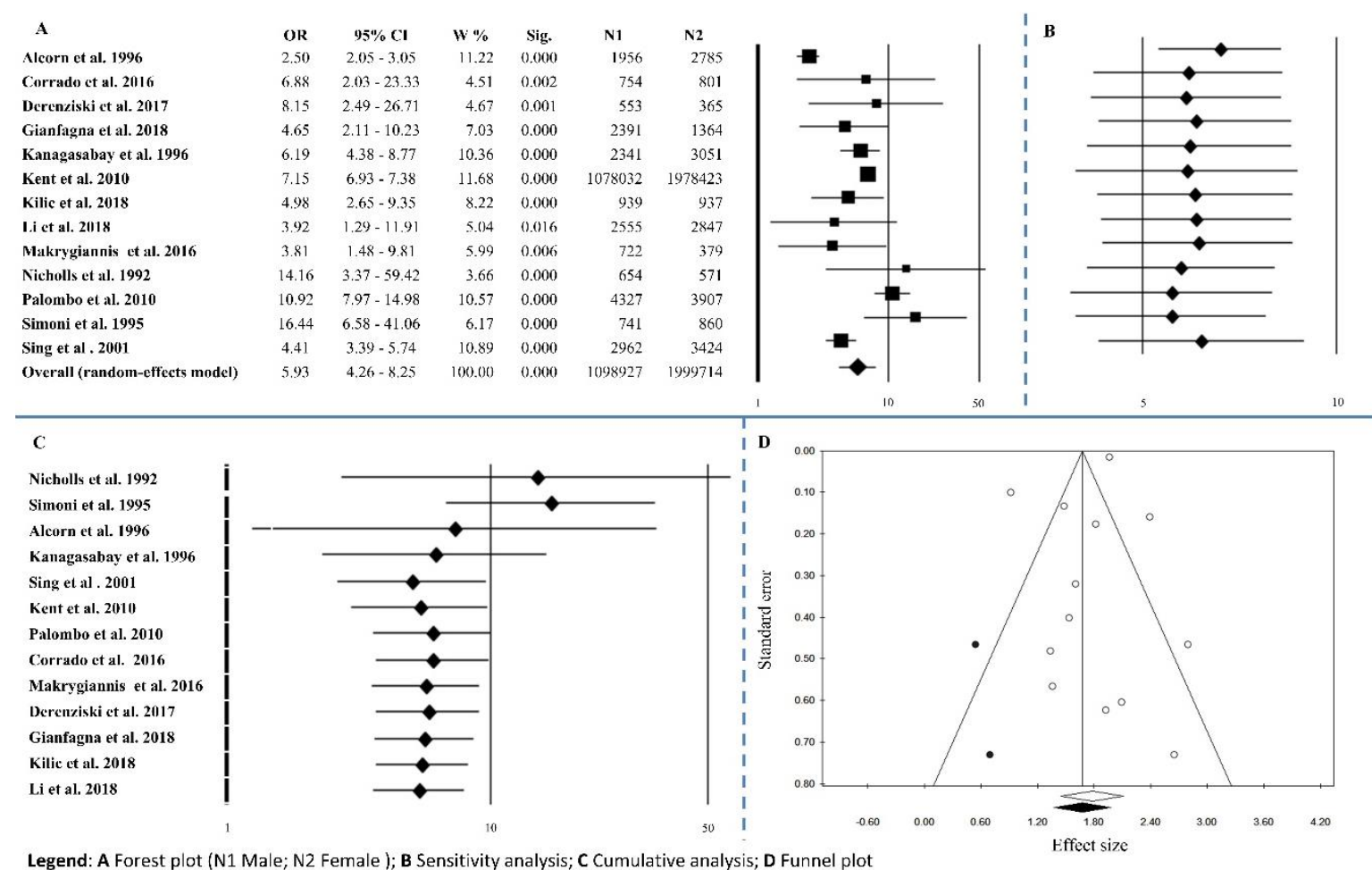

Legend: A Forest plot (N1 Male; N2 Female ); B Sensitivity analysis; C Cumulative analysis; D Funnel plot

Figure 2. Gender. (A) Forest plot (N1 Male; N2 Female); (B) sensitivity analysis; (C) cumulative analysis; (D) funnel plot.

Table 2. Meta-analysis with studies including male and female.

\begin{tabular}{|c|c|c|c|c|c|c|c|c|c|}
\hline \multirow[b]{2}{*}{ Risk Factors } & \multicolumn{4}{|c|}{ Pooled Analysis } & \multicolumn{3}{|c|}{ Heterogeneity } & \multicolumn{2}{|c|}{ Publication Bias } \\
\hline & $\begin{array}{c}\mathbf{k}=n . \text { of } \\
\text { Studies }\end{array}$ & $\begin{array}{c}\text { ES } \\
\text { (OR) }\end{array}$ & $95 \% \mathrm{CI}$ & $p$-Value & Q & $p$-Value & $I^{2}$ & $\begin{array}{l}\text { Egger } \\
p \text {-Value }\end{array}$ & $\begin{array}{l}\text { Begg and } \\
\text { Mazumdar } \\
p \text {-Value }\end{array}$ \\
\hline Gender & 13 & 5.93 & $4.26-8.25$ & $<0.0001$ & 132.89 & $<0.0001$ & 90.97 & 0.339 & 0.542 \\
\hline Smoking habits & 6 & 2.97 & $1.20-7.30$ & 0.018 & 390.71 & $<0.0001$ & 98.72 & 0.229 & 0.573 \\
\hline Hypertension & 8 & 1.55 & $1.02-2.34$ & 0.039 & 112.34 & $<0.0001$ & 93.77 & 0.127 & 0.322 \\
\hline Diabetes mellitus & 6 & 1.18 & $0.99-1.41$ & 0.067 & 8.45 & 0.133 & 40.85 & 0.008 & 0.851 \\
\hline $\begin{array}{l}\text { Coronary Artery Disease } \\
\text { (CAD) }\end{array}$ & 5 & 2.29 & $1.75-3.01$ & $<0.0001$ & 5.98 & 0.200 & 33.15 & 0.032 & 0.624 \\
\hline Family history of AAA & 4 & 9.64 & $1.72-53.98$ & 0.01 & 30.77 & $<0.0001$ & 90.25 & 0.467 & 0.174 \\
\hline
\end{tabular}




\subsubsection{Smoking Habits}

Six papers reported information about smoking habits. The overall effect size was $\mathrm{OR}=2.97$ (1.20-7.30), $p=0.018$, with $\mathrm{Q}=390.71, I^{2}=98.72, p<0.0001$ (Figure 3A and Table 2). Sensitivity analysis showed an unequal trend among studies (Figure $3 \mathrm{~B}$ ). Cumulative analysis indicated that all the studies agreed except for Simoni's [36] (Figure 3C). Publication bias analysis by the trim and fill method did not involve the exclusion of any papers (0 filled studies) (Figure 3D). The absence of publication bias is underlined by the results of Egger's linear regression test and Begg's and Mazumdar's rank correlation tests that were not statistically significant ( $p=0.229$ and $p=0.573$, respectively) (Table 2). Meta-regression analysis was not statistically significant $p=0.633$.

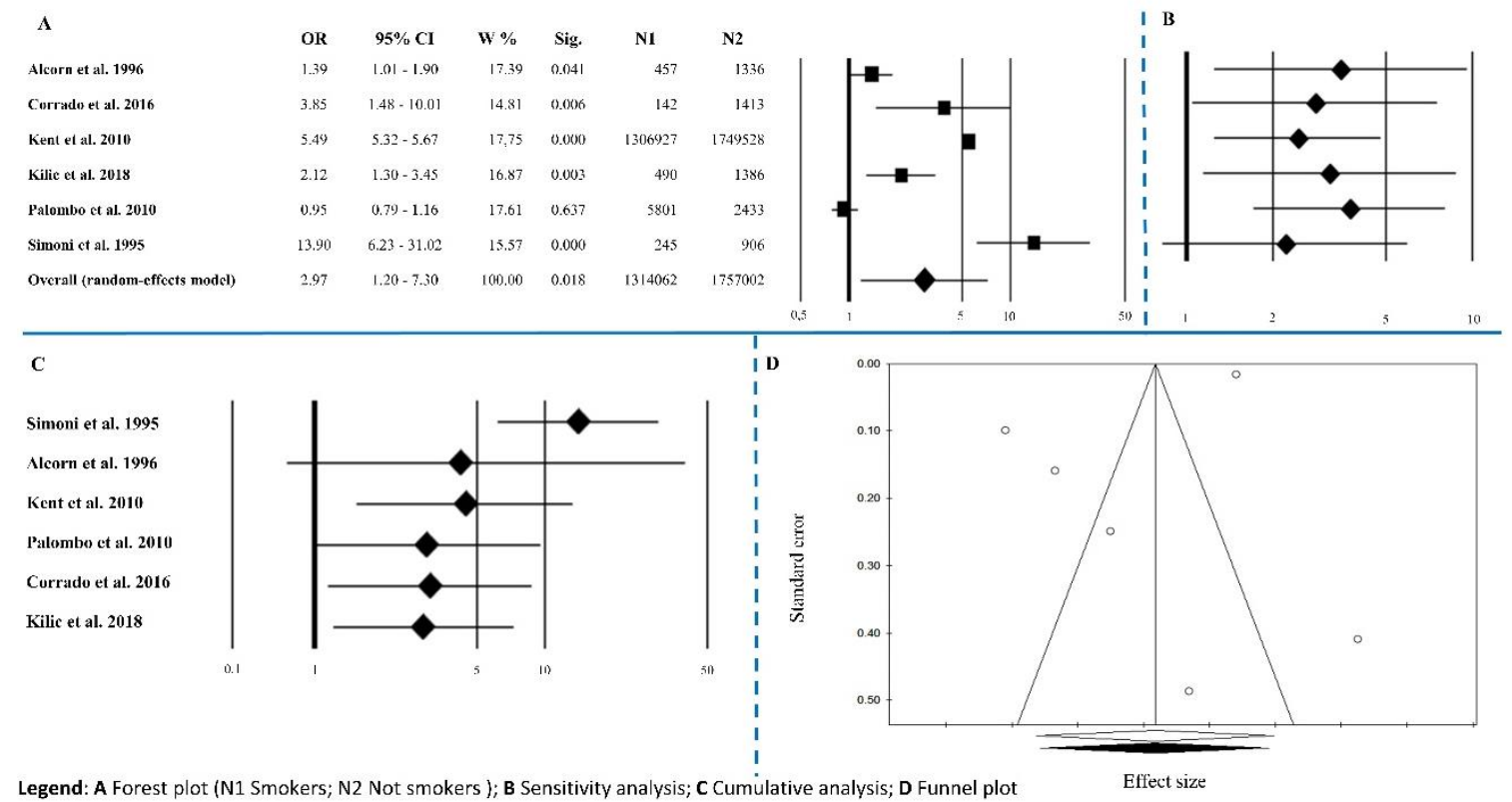

Figure 3. Smoker. (A) Forest plot (N1 Smokers; N2 Not smokers); (B) sensitivity analysis; (C) cumulative analysis; (D) funnel plot.

\subsubsection{Hypertension}

Eight papers contained frequencies on hypertension. The overall effect size was $\mathrm{OR}=1.55$ (1.02-2.34), $p=0.039$, with $\mathrm{Q}=112.34, I^{2}=93.77, p<0.0001$ (Figure $4 \mathrm{~A}$ and Table 2 ). Sensitivity analysis showed an equal trend among studies except for Kent's [55] (Figure 4B). Cumulative analysis indicated that all the studies agreed except for Alcorn's [57] (Figure 4C). Publication bias analysis by the trim and fill method did not exclude any papers (0 filled studies) (Figure 4D). The absence of publication bias is highlighted from results of Egger's linear regression test and Begg's and Mazumdar's rank correlation tests that were not statistically significant ( $p=0.127$ and $p=0.322$, respectively) (Table 2). Meta-regression analysis was not statistically significant $p=0.202$. 


Al-Zahrani et al. 1996
Alcorn et al. 1996
Corrado et al. 2016
Kent et al. 2010
Kilic et al. 2018
Li ct al. 2018
Palombo ct al. 2010
Simoni et al. 1995
Overall (random-effects model)

Overall (random-effects model) c

Simoni et al. 1995 Al Zahrani et al. 1996 Alcorn et al. 1996 Kent et al. 2010 Palombo et al. 2010 Corrado ct al. 2016 Kilic et al. 2018 Li et al. 2018
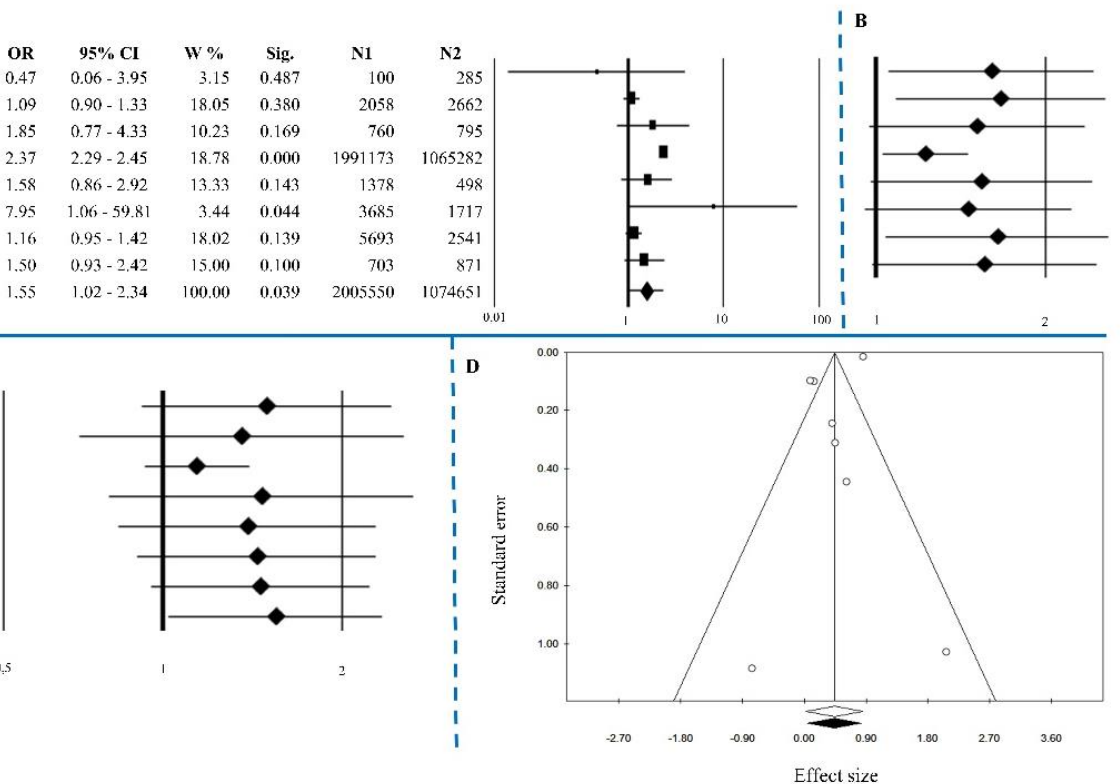

Legend: A Forest plot (N1 Hypertension; N2 Not hypertension); B Sensitivity analysis; C Cumulative analysis; D Funnel plot

Figure 4. Hypertension. (A) Forest plot (N1 Hypertension; N2 Not hypertension); (B) sensitivity analysis; (C) cumulative analysis; (D) funnel plot.

\subsubsection{Diabetes Mellitus}

Six papers reported information on diabetes mellitus. The overall effect size was $\mathrm{OR}=1.18$ (0.99-1.41),$p=0.067$, with $\mathrm{Q}=8.45, I^{2}=40.85, p=0.133$ (Figure $5 \mathrm{~A}$ and Table 2). Sensitivity analysis showed an unequal trend among studies (Figure $5 \mathrm{~B}$ ). Cumulative analysis indicated that all the studies agreed except for Simoni's [36] (Figure 5C). Publication bias analysis by the trim and fill method did not involve the exclusion of any papers (0 filled studies) (Figure 5D). According to Egger's linear regression test $(p=0.008)$ there is bias, but Begg's and Mazumdar's rank correlation tests $(p=0.851)$ do not show presence of publication bias (Table 2).

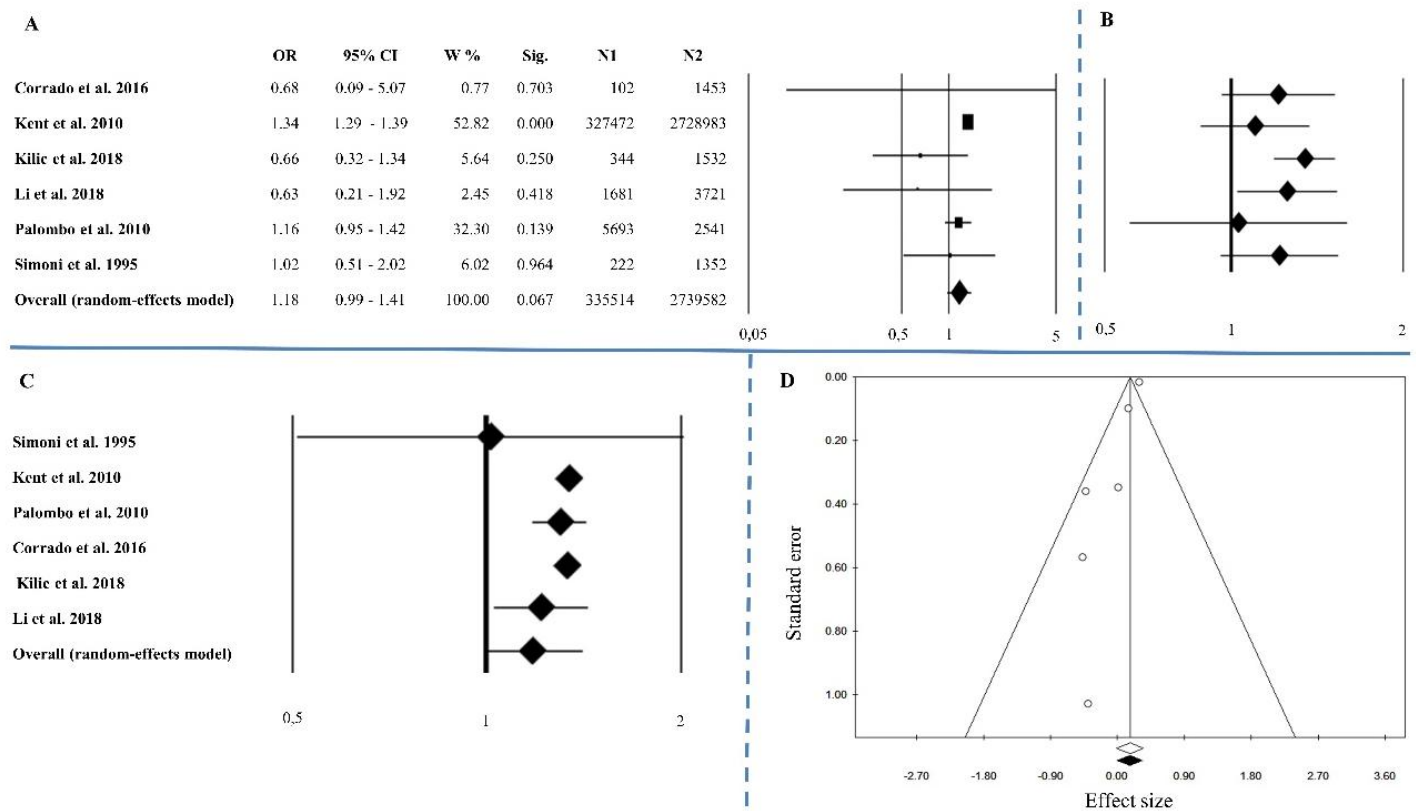

Legend: A Forest plot (N1 Diabetes; N2 Not Diabetes); B Sensitivity analysis; C Cumulative analysis; D Funnel plot

Figure 5. Diabetes. (A) Forest plot (N1 Diabetes; N2 Not Diabetes); (B) sensitivity analysis; (C) cumulative analysis; (D) funnel plot. 


\subsubsection{Coronary Artery Disease}

Information on Coronary Artery Disease was reported in 5 studies. The overall effect size was $\mathrm{OR}=2.29$ (1.75-3.01), $p<0.0001$, with $\mathrm{Q}=5.98, I^{2}=33.15, p=0.200$ (Figure 6A and Table 2). Sensitivity analysis showed an equal trend among studies except for Alcorn's and Kilic's [12,57] (Figure 6B). Cumulative analysis indicated that all the studies agreed except for Simoni's [36] (Figure 6C). Publication bias analysis, by the trim and fill method, filled two studies (Figure 6D). The results of Egger's linear regression test are statistically significant $(p=0.032)$ but, Begg's and Mazumdar's rank correlation tests were not statistically significant $(p=0.624)$ (Table 2$)$.

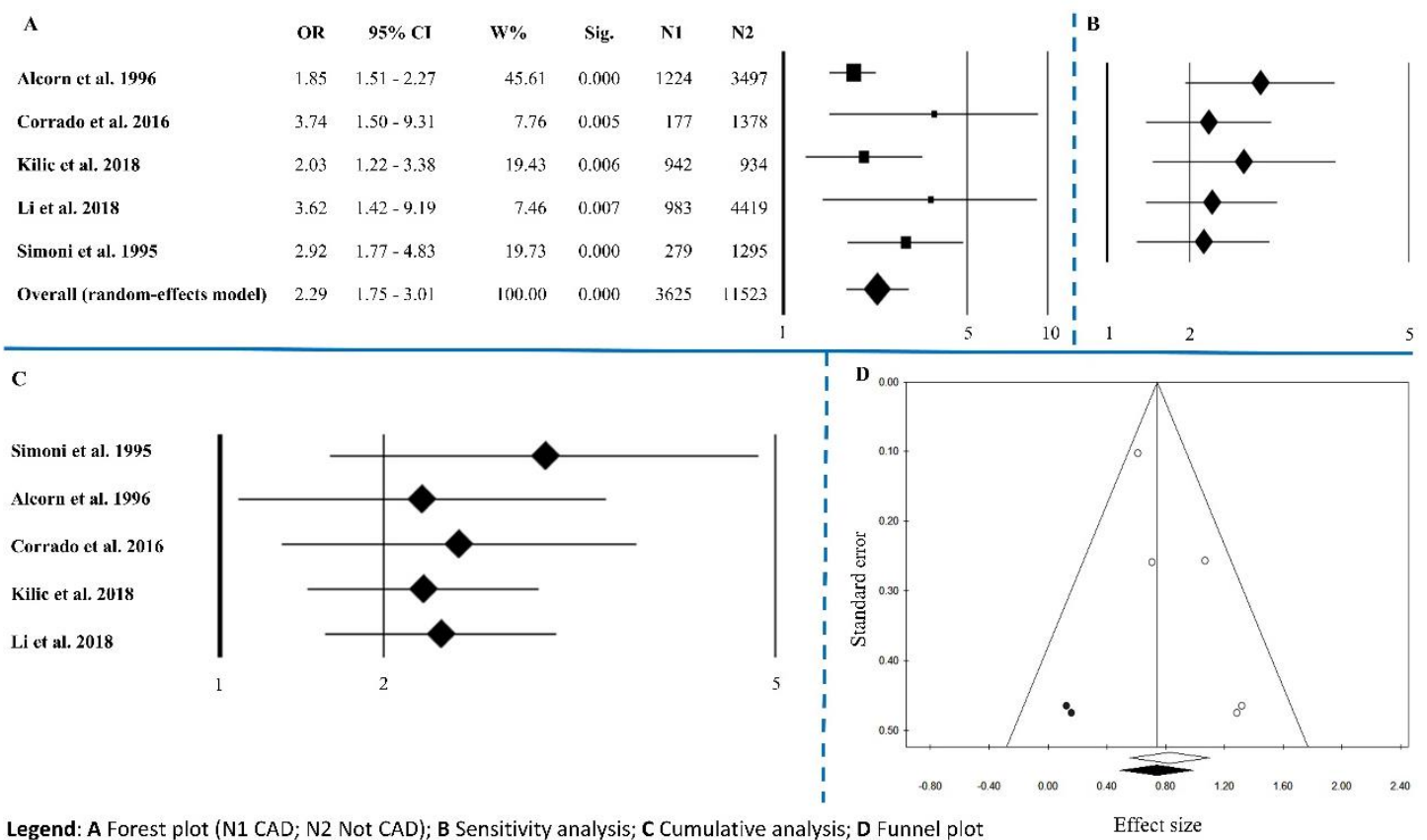

Figure 6. Coronary Artery Diseases (CAD). (A) Forest plot (N1 CAD; N2 Not CAD); (B) sensitivity analysis; (C) cumulative analysis; (D) funnel plot.

\subsubsection{Family History of Abdominal Aortic Aneurysm}

Four studies reported information on family history of AAA. The overall effect size was $\mathrm{OR}=9.64$ (1.72-53.98), $p=0.01$, with $\mathrm{Q}=30.77, \mathrm{I}^{2}=90.25, p<0.0001$ (Figure 7A and Table 2). Sensitivity analysis showed an equal trend between studies except for Li's [15] (Figure 7B). Cumulative analysis indicated that all the studies agreed except for Li's [15] (Figure 7C). Publication bias analysis by the trim and fill method did not exclude any papers (0 filled studies) (Figure 7D). The absence of publication bias is highlighted from Egger's linear regression test and Begg's and Mazumdar's rank correlation tests that were not statistically significant $(p=0.467$ and $p=0.174$, respectively) (Table 2). Meta-regression analysis was not statistically significant $p=0.551$. 

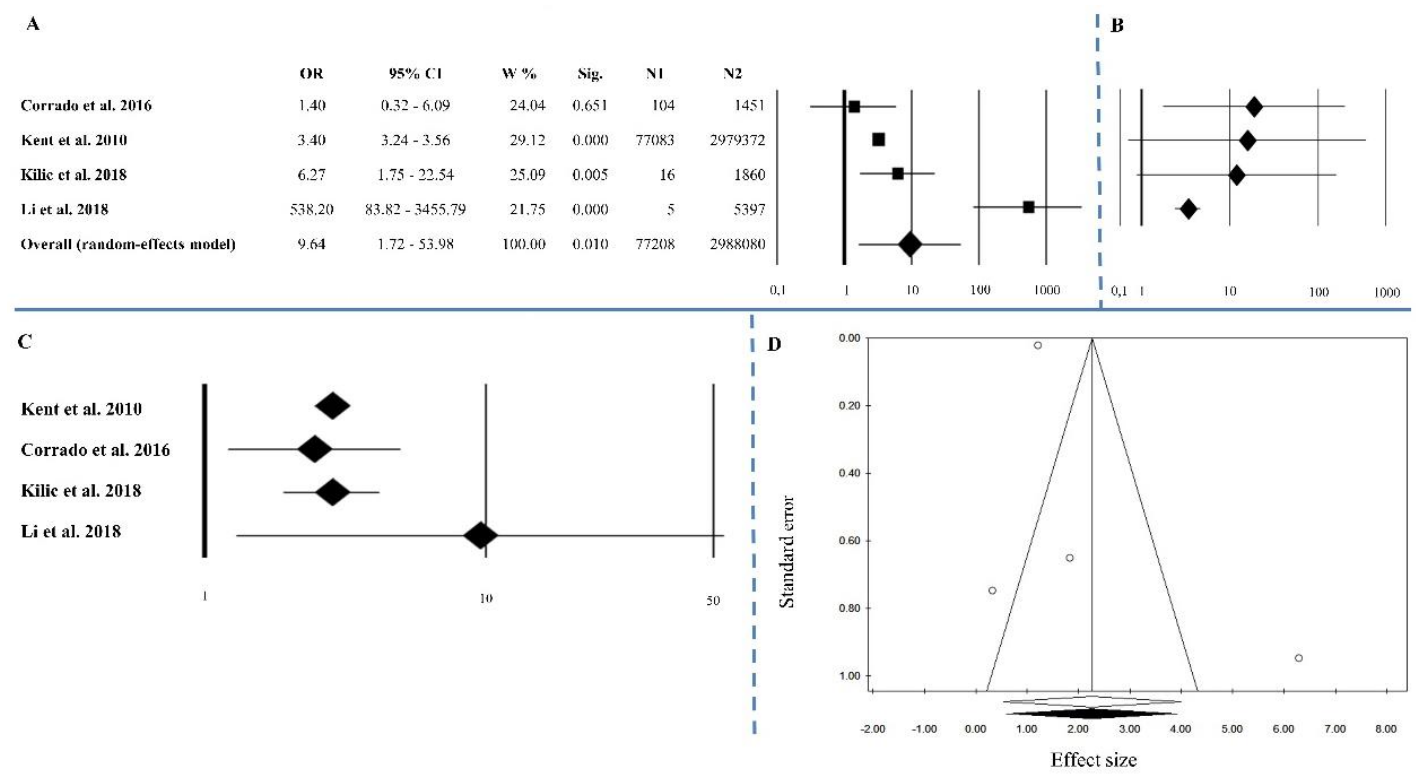

Legend: A Forest plot (N1 Family history; N2 Not Family history); B Sensitivity analysis; C Cumulative analysis; D Funnel plot

Figure 7. Family history of abdominal aortic aneurysm (AAA). (A) Forest plot (N1 Family history; N2 Not Family history); (B) sensitivity analysis; (C) cumulative analysis; (D) funnel plot.

\section{Discussion}

In this study we show the results of a systematic review and a meta-analysis of observational studies. Some Italian studies included in our systematic review have shown AAA prevalence between $1.4 \%$ and $6.2 \%[13,19,35,36]$. Other studies showed a range of prevalence AAA from $0.3 \%$ to $12.4 \%$ or between $0.5 \%$ and $9.3 \%[4,9-11,13,18,19,33,51-59]$. These differences could be due to the different age ranges of the enrolled patients in the studies. A previous meta-analysis on studies about the role of risk factors such as gender, smoking habits, hypertension, diabetes mellitus, myocardial infarction and peripheral vascular disease in development of AAA was conducted in 2004 [64]. We performed a new meta-analysis considering the same risk factors and adding CAD and family history of AAA with more updated studies. In respect to previous meta-analysis [64], we added the funnel plot to examine the effect sizes estimated from individual studies as measure of their precision; sensitivity analysis to check the stability of study findings and estimate how the overall effect size could be modified by removal of one study; cumulative analysis to evaluate the trend between studies in relation to publication year.

We performed a meta-analysis using the random effect according to Der Simonian and Laird for calculate the overall effect-size [65].

Respect to the systematic review, the first important aspect that has emerged is that the organized screening is nationwide only in the UK and Sweden [40-44,58], while in other countries it is mainly local (regional or provincial), as in Italy. In particular, Italy is one of the countries with a substantial number of screening programmes, but most of these are organized mainly in the North (Genoa, Como, Varese) $[13,19,35,36]$.

The second important consideration is that only high-income level countries have activated AAA screening programmes as highlighted in cancer screening [66,67]. Therefore, this aspect should be considered in order to avoid social inequalities and greater flexibility for access to treatment and to prevention of AAA. Altobelli et al. [66-70] showed that in many European countries there are no primary prevention campaigns against the main risk factors related to non-communicable diseases and therefore in these nations there is scarce attention to prevention. Sildoff et al. [71] compared the mortality due to AAA in some countries where population-based screening is active, like UK, Sweden, Australia, compared to those where there is no population-based screening, like Austria, Hungary and Romania. In those countries where screening campaigns are active, the mortality rate is 
in constant decline. The introduction of AAA screening saves lives, prevents rupture risk, coincides with a lower prevalence of the disease, reduces the incidence of aneurysm rupture, and decreases the mortality $[1,9,19,35,37,41,58,71,72]$. Kim et al. [71] demonstrated that the group invited to be screened had approximately half the risk. The risk reduction was even greater in patients who attended the screening.

Regarding the development of AAA, smoking is the main risk factor correlated to AAA [4,9-13,15-19,33,63,73]. The results of our meta-analysis, relative to male gender and smoking habits, are in line with those of previous research $[4,11-13,15,19,35,36,45,48,51,55,57]$. In our analysis, male smokers have a major risk of AAA. In agreement with some authors [11-13,15,19,35,36,48,51,55,57], our results confirm male gender and smoking habits as risk factors for AAA ( $\mathrm{OR}=5.93$ and 2.97, respectively). In countries where the consumption of cigarettes has been reduced, a lower prevalence of AAA has been shown [13,18,19,42,55,59,74]. According to Laroche et al. [18] the reduction in AAA prevalence is parallel to the reduction in tobacco consumption, but anti-smoking information campaigns are insufficient.

Smoking is closely correlated with the diameter of the aorta; it, indeed, is bigger in smokers compared to non-smokers and also according to Al-Zahrani et al. [53] AAA was eight times more in smokers than non-smokers. Therefore, large aneurysm is considered high-risk for rupture and its reduction is essential for reducing aneurysm-related death [54].

Current smoking is associated with occurrence of AAA at younger ages [55]. Moreover, risk of AAA is higher for current smokers than past smokers and it increases with duration of smoking [55].

In the Multicentre Aneurysm Screening Study (MASS) the benefit of quitting smoking has been shown and this benefit leads to decrease of aortic rupture [74].

Some studies that include females show that AAA prevalence is always higher compared to males $[4,11,17,18,34,35,39,42,44,47,50,51,54,55]$. It is important to underline that association between males and AAA could be attributed to a greater predisposition of males than to females to cardiovascular disease, known as "male disadvantage" [75].

According Forsdahl et al. [63] male gender, advancing age, low High-density lipoprotein (HDL) cholesterol and smoking are risk factors associated with AAA and therefore they are factors to be investigated. Other studies have shown an association among AAA and the following diseases: Hypertension, peripheral vascular disease, ischemic heart disease, previous myocardial infarction, chronic obstructive respiratory disease, symptoms of occlusive arterial and coronary artery $[44,46,53]$. Takei et al. [52] considered risk factors in population target, atherosclerosis, hypertension, obesity, abnormal serum lipid levels and history of smoking. In our meta-analysis hypertension presents an effect size of 1.55 and $p=0.039$. Regard to the role of hypertension as potential risk factor for AAA some authors $[8,37,44,60,63]$ are in disagreement. Alcorn et al. [57] suggest that individuals with hypertension are more likely to be evaluated clinically for the identification of AAA and this leads to a greater number of AAA diagnoses. Our results show that family history of AAA is also a risk factor, but it is important to underline that family history should be considered with caution because the confidence interval is wide enough, therefore effect size pooled could be influenced.

Respect to gender, smoking habits, hypertension and family history of AAA, the data of our meta-analysis showed presence of heterogeneity. The absence of homogeneity could be due to different sample sizes among studies included in our meta-analysis. Egger linear regression test and mostly Begg's and Mazumdar's rank correlation tests show absence of a publication bias. The homogeneity among studies included was supported by Cochrane's and Higgins's tests. For such risk factors there is no publication bias. In agreement with previous studies diabetes mellitus is not statistically significant $[4,11,12,15,16,19]$. De Rango and collegues [76] suppose that high blood glucose forms advanced glycation-end products due to the non-enzymatic oxidation of vascular matrix protein, which over time, becomes less inclined to dilatation and leads to a different sphygmic wave propagation. Our study has some strengths and limitations. The strength of this meta-analysis conducted within the context of a systematic review of descriptive observational studies over a period 
of 25 years, offers an efficient and potent tool to summarize the clinical evidence accrued on this specific clinical question. Despite its strength, that includes statistical precision and analysis external validity, there are some limitations due to primary studies, which do not allow subgroup analyzes due to lack of data collection; moreover, it is not possible to establish temporal sequence between exposure to risk factors and the onset of the aneurysm because it is a meta-analysis of prevalence studies.

\section{Conclusions}

Abdominal aortic aneurysm is correlated to risk factors associated to an incorrect lifestyle, such as smoking, a wrong diet, absence of regular exercise and gender. Kent et al. [55] found that consumption of fruit, vegetables, nuts and regular exercise reduces the risk of AAA. The importance of a correct diet is also highlighted in other diseases related to nutrition [77,78]. Male gender and family history of AAA are "non-modifiable" factors; while diabetes mellitus, smoking habits, hypertension, CAD can be avoided and, therefore, are "modifiable." In fact, it is important to underline that quitting smoking, following a correct diet and practicing sports could reduce risk of AAA and consequently the mortality due to rupture of the aorta.

In addition, our systematic review showed that all countries where AAA screening was set up, were at high income level and the majority belong to Western Europe (United Kingdom, Sweden, Italy, Poland, Spain, Belgium). The purpose of this meta-analysis was to provide a contribution to future research on the role of common risk factors, such as gender, smoking habits, hypertension, CAD, family history of AAA and to address AAA screening to target population at high risk.

The best method of AAA screening is ultrasonography, which is cheap, accurate, safe, rapid, noninvasive, has good reproducibility and is cost-effective.

In conclusion, these findings, together with continuous lengthening of average life, foreshadow a real "vascular emergency." Prevention is a fundamental aspect of modern medicine that should be promoted and incentivized in a healthcare system that takes care not only of the illness itself but of the person, even when one is apparently in good health.

Author Contributions: E.A. contributed to this paper with conception and design of the study, literature review, developed statistical analysis, drafting and critical revision and editing. L.R. participated to literature search, participated to build database. R.F. and V.F.P. participated to acquire the data. All authors have approved the final version of manuscript.

Funding: Please add: This research received no external funding.

Conflicts of Interest: The authors declare no conflict of interest.

\section{References}

1. Moll, F.L.; Powell, J.T.; Fraedrich, G.; Verzini, F.; Haulon, S.; Waltham, M.; van Herwaarden, J.A.; Holt, P.J.; van Keulen, J.W.; Rantner, B.; et al. European Society for Vascular Surgery. Management of abdominal aortic aneurysms clinical practice guidelines of the European society for vascular surgery. Eur. J. Vasc. Endovasc. Surg. 2011, 41 (Suppl. 1), S1-S58. [CrossRef] [PubMed]

2. Stather, P.W.; Sidloff, D.A.; Dattani, N.; Gokani, V.J.; Choke, E.; Sayers, R.D.; Bown, M.J. Meta-analysis and meta-regression analysis of biomarkers for abdominal aortic aneurysm. Br. J. Surg. 2014, 101, 1358-1372. [CrossRef] [PubMed]

3. Krumholz, H.M.; Keenan, P.S.; Brush, J.E., Jr.; Bufalino, V.J; Chernew, M.E.; Epstein, A.J;; Heidenreich, P.A.; Ho, V.; Masoudi, F.A.; Matchar, D.B.; et al. Standards for measures used for public reporting of efficiency in health care: A scientific statement from the American Heart Association Interdisciplinary Council on Quality of Care and Outcomes research and the American College of Cardiology Foundation. J. Am. Coll. Cardiol. 2008, 52, 1518-1526. [CrossRef] [PubMed]

4. Makrygiannis, G.; Labalue, P.; Erpicum, M.; Schlitz, M.; Seidel, L.; El Hachemi, M.; Gangolf, M.; Albert, A.; Defraigne, J.O.; Lindholt, J.S.; et al. Extending abnominal aortic aneurysm detection to older age older age groups: Preliminary results from the Liege screening programme. Ann. Vasc. Surg. 2016, 36, 55-63. [CrossRef] [PubMed] 
5. Institute for Health Metrics and Evaluation. Global Burden of Disease Study. Available online: http//www. healthmetricsandevaluation.org/gbd/visualizations/gbd-cause-patterns (accessed on 30 June 2018).

6. Kniemeyer, H.W.; Kessler, T.; Reber, P.U.; Ris, H.B.; Hakki, H.; Widmer, M.K. Treatment of ruptured abdominal aortic aneurysm, a permanent challenge or a waste of resources? Prediction of outcome using a multi-organ-dysfunction score. Eur. J. Vasc. Endovasc. Surg. 2000, 19, 190-196. [CrossRef] [PubMed]

7. Thompson, S.G.; Brown, L.C.; Sweeting, M.J.; Bown, M.J.; Kim, L.G.; Glover, M.J.; Buxton, M.; Powell, J. Systematic review and meta-analysis of the growth and rupture rates of small abdominal aortic aneurysms: Implications for surveillance intervals and their cost-effectiveness. Health Technol. Assess. 2013, 17, 1-118. [CrossRef] [PubMed]

8. Durieux, R.; Van Damme, H.; Labropoulos, N.; Yazici, A.; Legrand, V.; Albert, A.; Defraigne, J.O.; Sakalihasan, N. High prevalence of abdominal aortic aneurysm in patients with three-vessel coronary artery disease. Eur. J. Vasc. Endovasc. Surg. 2014, 47, 273-278. [CrossRef] [PubMed]

9. Salcedo Jódar, L.; Alcázar Carmona, P.; Tenías Burillo, J.M.; García Tejada, R. Prevalence of abdominal aortic aneurysm in a rural population of 65-80 year-old males. Semergen 2014, 40, 425-430. [CrossRef]

10. Salvador-González, B.; Martín-Baranera, M.; Borque-Ortega, Á.; Sáez-Sáez, R.M.; de Albert-Delas Vigo, M.; Carreño-García, E.; Tarín-Masriera, L.; Badia-Millán, P.; Martínez-Gil, M.; Torrabadella-Fàbrega, J. Prevalence of Abdominal Aortic Aneurysm in Men Aged 65-74 Years in a Metropolitan Area in North-East Spain. Eur. J. Vasc. Endovasc. Surg. 2016, 52, 75-81. [CrossRef]

11. Dereziński, T.L.; Fórmankiewicz, B.; Migdalski, A.; Brazis, P.; Jakubowski, G.; Woda, Ł.; Jawień, A. The prevalence of abdominal aortic aneurysms in the rural/urban population in central Poland-Gniewkowo Aortic Study. Kardiol. Pol. 2017, 75, 705-710. [CrossRef]

12. Kilic, S.; Saracoglu, E.; Cekici, Y. Clinical Efficacy of Transthoracic Echocardiography for Screening Abdominal Aortic Aneurysm in Turkish Patients. Acta Cardiol. Sin. 2018, 34, 137-143. [PubMed]

13. Gianfagna, F.; Veronesi, G.; Tozzi, M.; Tarallo, A.; Borchini, R.; Ferrario, M.M.; Bertù, L.; Montonati, A.; Castelli, P.; Mara, L.; et al. Prevalence of abdominal aortic aneurysms in the general population and in subgroups at high cardiovascular risk in Italy. Results of the RoCAV population based study. Eur. J. Vasc. Endovasc. Surg. 2018, 55, 633-639. [CrossRef] [PubMed]

14. Bohlin, C.; Fröjd, A.; Wanhainen, M.; Björck, M. Change in smoking habits after been screened for abdominal aortic aneurysm. Eur. J. Vasc. Endovasc. Surg. 2014, 48, 138-143. [CrossRef] [PubMed]

15. Li, K.; Zhang, K.; Li, T.; Zhai, S. Primary results of abdominal aortic aneurysm screening in the at-risk residents in middle China. BMC Cardiovasc. Disord. 2018, 18, 60. [CrossRef] [PubMed]

16. Belloch García, S.L. Abdominal aortic aneurysm. Prevalence and associated risk factors in a population of patients hospitalised in Internal Medicine. Rev. Clin. Esp. 2018, 218, 455-460. [CrossRef] [PubMed]

17. Itoga, N.K.; Rothenberg, K.A.; Suarez, P.; Ho, T.V.; Mell, M.W.; Xu, B.; Curtin, C.M.; Dalman, R.L. Metformin prescription status and abdominal aortic aneurysm disease progression in the U.S. veteran population. J. Vasc. Surg. 2018. [CrossRef]

18. Laroche, J.P.; Becker, F.; Baud, J.M.; Miserey, G.; Jaussent, A.; Picot, M.C.; Bura-Rivière, A.; Quéré, I. Ultrasound screening of abdominal aortic aneurysm: Lessons from Vesale 2013. J. Mal. Vasc. 2015, 40, 340-349. [CrossRef]

19. Corrado, G.; Durante, A.; Genchi, V.; Trabattoni, L.; Beretta, S.; Rovelli, E.; Foglia-Manzillo, G.; Ferrari, G. Prevalence of previously undiagnosed abdominal aortic aneurysms in the area of Como: The ComoCuore "looking for AAA" ultrasonography screening. Int. J. Cardiovasc. Imaging 2016, 32, 1213-1217. [CrossRef]

20. Saratzis, A.; Bown, M.J. The genetic basis for aortic aneurysmal disease. Heart 2014, 100, 916-922. [CrossRef]

21. Toghill, B.J.; Saratzis, A.; Harrison, S.C.; Verissimo, A.R.; Mallon, E.B.; Bown, M.J. The potential role of DNA methylation in the pathogenesis of abdominal aortic aneurysm. Atherosclerosis 2015, 241, 121-129. [CrossRef]

22. Ashton, H.A.; Gao, L.; Kim, L.G.; Druce, P.S.; Thompson, S.G.; Scott, R.A. Fifteen-year follow-up of a randomized clinical trial of ultrasonographic screening for abdominal aortic aneurysms. Br. J. Surg. 2007, 94, 696-701. [CrossRef] [PubMed]

23. Lindholt, J.S.; Sørensen, J.; Søgaard, R.; Henneberg, E.W. Long-term benefit and cost-effectiveness analysis of screening for abdominal aortic aneurysms from a randomized controlled trial. Br. J. Surg. 2010, 97, 826-834. [CrossRef] [PubMed] 
24. Norman, P.E.; Jamrozik, K.; Lawrence-Brown, M.M.; Le, M.T.; Spencer, C.A.; Tuohy, R.J.; Parsons, R.W.; Dickinson, J.A. Population based randomized controlled trial on impact of screening on mortality from abdominal aortic aneurysm. BMJ 2004, 329, 1259, Erratum in 2005, 330, 596. [CrossRef]

25. Darwood, R.J.; Brooks, M.J. The impact of decreasing abdominal aortic aneurysm prevalence on a local aneurysm screening programme. Eur. J. Vasc. Endovasc. Surg. 2012, 44, 45-50. [CrossRef]

26. Thompson, S.G.; Ashton, H.A.; Gao, L.; Scott, R.A. Multicentre Aneurysm Screening Study Group. Screening men for abdominal aortic aneurysm: 10 year mortality and cost effectiveness results from the randomized Multicentre Aneurysm Screening Study. BMJ 2009, 338, b2307. [CrossRef]

27. Ali, M.U.; Fitzpatrick-Lewis, D.; Miller, J.; Warren, R.; Kenny, M.; Sherifali, D.; Raina, P. Screening for abdominal aortic aneurysm in asymptomatic adults. J. Vasc. Surg. 2016, 64, 1855-1868. [CrossRef]

28. Stather, P.W.; Dattani, N.; Bown, M.J.; Earnshaw, J.J.; Lees, T.A. International variations in AAA screening. Eur. J. Vasc. Endovasc. Surg. 2013, 45, 231-234. [CrossRef]

29. Available online: https://www.uspreventiveservicestaskforce.org/Page/Document/ UpdateSummaryFinal/abdominal-aortic-aneurysm-screening (accessed on 31 May 2017).

30. Moher, D.; Liberati, A.; Tetzlaff, J.; Altman, D.G.; PRISMA Group. Preferred reporting items for systematic reviews and meta-analyses: The PRISMA statement. PLoS Med. 2009, 6, e1000097. [CrossRef]

31. Egger, M.; Davey Smith, G.; Schneider, M.; Minder, C. Bias in meta-analysis detected by a simple, graphical test. BMJ 1997, 315, 629-634. [CrossRef]

32. Begg, C.B.; Mazumdar, M. Operating characteristics of a rank correlation test for publication bias. Biometrics 1994, 50, 1088-1101. [CrossRef]

33. Vazquez, C.; Sakalihasan, N.; D'Harcour, J.B.; Limet, R. Routine ultrasound screening for abdominal aortic aneurysm among 65- and 75-year-old men in a city of 200,000 inhabitants. Ann. Vasc. Surg. 1998, 12, 544-549. [CrossRef] [PubMed]

34. Kvist, T.V.; Lindholt, J.S.; Rasmussen, L.M.; Søgaard, R.; Lambrechtsen, J.; Steffensen, F.H.; Frost, L.; Olsen, M.H.; Mickley, H.; Hallas, J.; et al. The DanCavas Pilot Study of Multifaceted Screening for Subclinical Cardiovascular Disease in Men and Women Aged 65-74 Years. Eur. J. Vasc. Endovasc. Surg. 2017, 53, $123-131$. [CrossRef] [PubMed]

35. Palombo, D.; Lucertini, G.; Pane, B.; Mazzei, R.; Spinella, G.; Brasesco, P.C. District-based abdominal aortic aneurysm screening in population aged 65 years and older. J. Cardiovasc. Surg. 2010, 51, 777-782.

36. Simoni, G.; Pastorino, C.; Perrone, R.; Ardia, A.; Gianrossi, R.; De Cian, F.; Cittadini, G., Jr.; Baiardi, A.; Bachi, V. Screening for abdominal aortic aneurysms and associated risk factors in a general population. Eur. J. Vasc. Endovasc. Surg. 1995, 10, 207-210. [CrossRef]

37. Jawien, A.; Formankiewicz, B.; Derezinski, T.; Migdalski, A.; Brazis, P.; Woda, L. Abdominal aortic aneurysm screening program in Poland. Gefasschirurgie 2014, 19, 545-548. [CrossRef] [PubMed]

38. Sisó-Almirall, A.; Kostov, B.; Navarro González, M.; Cararach Salami, D.; Pérez Jiménez, A.; Gilabert Solé, R.; Saumell, C.B.; Bach, L.D.; Martí, M.V.; González-de Paz, L.; et al. Abdominal aortic aneurysm screening program using hand-held ultrasound in primary healthcare. PLoS ONE 2017, 12, e0176877. [CrossRef] [PubMed]

39. Ortega-Martín, J.M.; Fernández-Morána, M.C.; Alonso-Álvareza, M.I.; García-Gimenob, M.; Fernández-Samosa, R.; Vaquero-Morilloa, F. The prevalence of abdominal aortic aneurysms in a high risk population. Angiologia 2007, 59, 305-315. [CrossRef]

40. Stackelberg, O.; Wolk, A.; Eliasson, K.; Hellberg, A.; Bersztel, A.; Larsson, S.C.; Orsini, N.; Wanhainen, A.; Björck, M. Lifestyle and Risk of Screening-Detected Abdominal Aortic Aneurysm in Men. J. Am. Heart Assoc. 2017, 6, e004725. [CrossRef]

41. Wanhainen, A.; Hultgren, R.; Linné, A.; Holst, J.; Gottsäter, A.; Langenskiöld, M.; Smidfelt, K.; Björck, M.; Svensjö, S.; Swedish Aneurysm Screening Study Group (SASS); et al. Outcome of the Swedish Nationwide Abdominal Aortic Aneurysm Screening Program. Swedish Aneurysm Screening Study Group (SASS). Circulation 2016, 134, 1141-1148. [CrossRef]

42. Hager, J.; Länne, T.; Carlsson, P.; Lundgren, F. Lower prevalence than expected when screening 70-year-old men for abdominal aortic aneurysm. Eur. J. Vasc. Endovasc. Surg. 2013, 46, 453-459. [CrossRef]

43. Svensjö, S.; Björck, M.; Wanhainen, A. Current prevalence of abdominal aortic aneurysm in 70-year-old women. Br. J. Surg. 2013, 100, 367-372. [CrossRef] [PubMed] 
44. Svensjö, S.; Björck, M.; Gürtelschmid, M.; Djavani Gidlund, K.; Hellberg, A.; Wanhainen, A. Low prevalence of abdominal aortic aneurysm among 65-year-old Swedish men indicates a change in the epidemiology of the disease. Circulation 2011, 124, 1118-1123. [CrossRef] [PubMed]

45. Kanagasabay, R.; Gajraj, H.; Pointon, L.; Scott, R.A. Co-morbidity in patients with abdominal aortic aneurysm. J. Med. Screen. 1996, 3, 208-210. [CrossRef]

46. Smith, F.C.; Grimshaw, G.M.; Paterson, I.S.; Shearman, C.P.; Hamer, J.D. Ultrasonographic screening for abdominal aortic aneurysm in an urban community. Br. J. Surg. 1993, 80, 1406-1409. [CrossRef] [PubMed]

47. Grimshaw, G.M.; Thompson, J.M.; Hamer, J.D. Prevalence of abdominal aortic aneurysm associated with hypertension in an urban population. J. Med. Screen. 1994, 1, 226-228. [CrossRef]

48. Singh, K.; Bønaa, K.H.; Jacobsen, B.K.; Bjørk, L.; Solberg, S. Prevalence of and risk factors for abdominal aortic aneurysms in a population-based study: The Tromsø Study. Am. J. Epidemiol. 2001, 154, 236-244. [CrossRef]

49. Krohn, C.D.; Kullmann, G.; Kvernebo, K.; Rosén, L.; Kroese, A. Ultrasonographic screening for abdominal aortic aneurysm. Eur. J. Surg. 1992, 158, 527-530.

50. Engelberger, S.; Rosso, R.; Sarti, M.; Del Grande, F.; Canevascini, R.; van den Berg, J.C.; Prouse, G.; Giovannacci, L. Ultrasound screening for abdominal aortic aneurysms. Swiss Med. Wkly. 2017, 147, w14412. [PubMed]

51. Nicholls, E.A.; Norman, P.E.; Lawrence-Brown, M.M.; Goodman, M.A.; Pedersen, B. Screening for abdominal aortic aneurysms in Western Australia. Aust. N. Z. J. Surg. 1992, 62, 858-861. [CrossRef]

52. Takei, H.; Ishikawa, S.; Otaki, A.; Sakata, K.; Aizaki, M.; Sato, Y.; Suzuki, M.; Ishikita, T.; Iino, Y.; Yokoe, T.; et al. Screening for abdominal aortic aneurysm and occlusive peripheral vascular disease in Japanese residents. Surg. Today 1995, 25, 608-611. [CrossRef]

53. Al-Zahrani, H.A.; Rawas, M.; Maimani, A.; Gasab, M.; Aba al Khail, B.A. Screening for abdominal aortic aneurysm in the Jeddah area, western Saudi Arabia. Cardiovasc. Surg. 1996, 4, 87-92. [CrossRef]

54. Chun, K.C.; Schmidt, A.S.; Bains, S.; Nguyen, A.T.; Samadzadeh, K.M.; Wilson, M.D.; Peters, J.H.; Lee, E.S. Surveillance outcomes of small abdominal aortic aneurysms identified from a large screening program. J. Vasc. Surg. 2016, 63, 55-61. [CrossRef] [PubMed]

55. Kent, K.C.; Zwolak, R.M.; Egorova, N.N.; Riles, T.S.; Manganaro, A.; Moskowitz, A.J.; Gelijns, A.C.; Greco, G. Analysis of risk factors for abdominal aortic aneurysm in a cohort of more than 3 million individuals. J. Vasc. Surg. 2010, 52, 539-548. [CrossRef] [PubMed]

56. Lederle, F.A.; Johnson, G.R.; Wilson, S.E.; Chute, E.P.; Hye, R.J.; Makaroun, M.S.; Barone, G.W.; Bandyk, D.; Moneta, G.L.; Makhoul, R.G. The aneurysm detection and management study screening program: Validation cohort and final results. Aneurysm Detection and Management Veterans Affairs Cooperative Study Investigators. Arch. Intern. Med. 2000, 160, 1425-1430. [CrossRef] [PubMed]

57. Alcorn, H.G.; Wolfson, S.K., Jr.; Sutton-Tyrrell, K.; Kuller, L.H.; O’Leary, D. Risk factors for abdominal aortic aneurysms in older adults enrolled in The Cardiovascular Health Study. Arterioscler. Thromb. Vasc. Biol. 1996, 16, 963-970. [CrossRef] [PubMed]

58. Oliver-Williams, C.; Sweeting, M.J.; Turton, G.; Parkin, D.; Cooper, D.; Rodd, C.; Thompson, S.G.; Earnshaw, J.J.; Gloucestershire and Swindon Abdominal Aortic Aneurysm Screening Programme. Lessons learned about prevalence and growth rates of abdominal aortic aneurysms from a 25-year ultrasound population screening programme. Br. J. Surg. 2018, 105, 68-74. [CrossRef] [PubMed]

59. Barba, Á.; Vega de Céniga, M.; Estallo, L.; de la Fuente, N.; Viviens, B.; Izagirre, M. Prevalence of abdominal aortic aneurysm is still high in certain areas of southern Europe. Ann. Vasc. Surg. 2013, 27, 1068-1073. [CrossRef] [PubMed]

60. Makrygiannis, G.; Mourmoura, E.; Spanos, K.; Roussas, N.; Kuivaniemi, H.; Sakalihasan, N.; Tsezou, A.; Giannoukas, A. Risk Factor Assessment in a Greek Cohort of Patients with Large Abdominal Aortic Aneurysms. Angiology 2018. [CrossRef] [PubMed]

61. Dahl, M.; Søgaard, R.; Frost, L.; Høgh, A.; Lindholt, J. Effectiveness of Screening Postmenopausal Women for Cardiovascular Diseases: A Population Based, Prospective Parallel Cohort Study. Eur. J. Vasc. Endovasc. Surg. 2018, 55, 721-729. [CrossRef] [PubMed]

62. Howard, D.P.J.; Banerjee, A.; Fairhead, J.F.; Handa, A.; Silver, L.E.; Rothwell, P.M. On behalf of the Oxford Vascular Study Population-Based study of incidence of Acute Abdominal Aortic Aneurysm with projected impact of screnning strategy. J. Am. Heart Assoc. 2015, 4, e001926. [CrossRef] 
63. Johansson, M.; Zahl, P.H.; Siersma, V.; Jørgensen, K.J.; Marklund, B.; Brodersen, J. Benefits and harms of screening men for abdominal aortic aneurysm in Sweden: A registry-based cohort study. Lancet 2018, 391, 2441-2447. [CrossRef]

64. Cornuz, J.; Sidoti Pinto, C.; Tevaearai, H.; Egger, M. Risk factors for asymptomatic abdominal aortic aneurysm: Systematic review and meta-analysis of population-based screening studies. Eur. J. Public Health 2004, 14, 343-349. [CrossRef] [PubMed]

65. DerSimonian, R.; Laird, N. Meta-analysis in clinical trials test. Control Clin. Trials 1986, 7, 177-188. [CrossRef]

66. Altobelli, E.; Rapacchietta, L.; Angeletti, P.M.; Barbante, L.; Profeta, F.V.; Faganno, R. Breast cancer screening programmes across the WHO European Region: Differences among Countries based on national income level. Int. J. Environ. Res. Public Health 2017, 14, 452. [CrossRef] [PubMed]

67. Altobelli, E.; D'Aloisio, F.; Angeletti, P.M. Colorectal cancer screening in countries of European Council outside of the EU-28. World J. Gastroenterol. 2016, 22, 4946-4957. [CrossRef]

68. Altobelli, E.; Lattanzi, A. Cervical carcinoma in the European Union: An update on disease burden screening program state of activation, and coverage as of March 2014. Int. J. Gynecol. Cancer 2015, 25, 474-483. [CrossRef]

69. Altobelli, E.; Lattanzi, A.; Paduano, R.; Varassi, G.; di Orio, F. Colorectal cancer prevention in Europe: Burden of disease and status of screening programs. Prev. Med. 2014, 62, 132-141. [CrossRef]

70. Altobelli, E.; Lattanzi, A. Brest cancer in European Union: An update of screening programmes as of March 2014 (review). Int. J. Oncol. 2014, 45, 1785-1792. [CrossRef]

71. Sildoff, D.; Stather, P.; Dattani, N.; Bown, M.; Thompson, J.; Sayers, R.; Choke, E. Aneurysm global epidemiology study: Public health measures can further abdominal aortic aneurysm mortality. Circulation 2014, 129, 747-753.

72. Kim, L.G.; Scott, R.A.P.; Asthon, H.A.; Thompson, S.G. For the Multicentre Aneurysm Screening Study Group A sustained mortality benefit from screening for Abdominal Aortic Aneurysm. Ann. Intern. Med. 2007, 146, 699-706. [CrossRef]

73. Scott, R.A.P.; Wilson, N.M.; Asthon, H.A.; Kay, D.N. Influence of screening on the incidence of ruptured abdominal aortic aneurysm: 5-year results of a randomized controlled study. Br. J. Surg. 1995, 82, 1066-1070. [CrossRef] [PubMed]

74. Forsdahl, S.H.; Singh, K.; Solberg, S.; Jacobsen, B.K. Risk factors for Abdominal Aortic Aneurism a 7-year prospective study: The Tromsø study 1994-2001. Circulation 2009, 119, 2202-2208. [CrossRef] [PubMed]

75. Thompson, S.G.; Ashton, H.A.; Gao, L.; Buxton, M.J.; Scott, R.A.P. On behalf of the Multicentre Aneurysm Screening Study (MASS) Group Final follow-up of Multicentre Aneurysm Screening Study (MASS) randomized trial od abdominal aortic aneurysm screening. Br. J. Surg. 2012, 99, 1649-1656. [CrossRef] [PubMed]

76. De Rango, P.; Farchioni, L.; Fiorucci, B.; Lenti, M. Diabetes and abdominal aortic aneurysms. Eur. J. Vasc. Endovasc. Surg. 2014, 47, 243-261. [CrossRef] [PubMed]

77. De Vos, L.C.; Noordzij, M.J.; Mulder, D.J.; Smit, A.J.; Lutgers, H.L.; Dullaart, R.P.; Kamphuisen, P.W.; Zeebregts, C.J.; Lefrandt, J.D. Skin autofluorescence as a measure of advanced glycation end products deposition is elevated in peripheral artery disease. Arterioscler. Thromb. Vasc. Biol. 2013, 33, 131-138. [CrossRef] [PubMed]

78. Altobelli, E.; Del Negro, V.; Angeletti, P.M.; Latella, G. Low-FODMAP Diet Improves Irritable Bowel Syndrome Symptoms: A Meta-Analysis. Nutrients 2017, 9, 940. [CrossRef] [PubMed]

(C) 2018 by the authors. Licensee MDPI, Basel, Switzerland. This article is an open access article distributed under the terms and conditions of the Creative Commons Attribution (CC BY) license (http://creativecommons.org/licenses/by/4.0/). 